Final Technical Report

"Expanding Cooperation between the Department of Energy (DOE) and the National Association of State Universities and Land-Grant Colleges (NASULGC)”

Submitted by

Ian L. Maw

Vice President, Food Agriculture and Natural Resource

On Behalf of

The National Association of State Universities and Land-Grant Colleges

DOE Award No.: DE-FG36-04GO14269

Award Recipient: The National Association of State Universities and Land-Grant Colleges.

Principal Investigator: Ian L. Maw, Vice President.

Background:

In early 203, Department of Energy(DOE) Assistant Secretary for the Office of Energy Efficiency and Renewable Energy, David Garman, met with the National Association of State Universities and Land-Grant Colleges(NASULGC) President Peter Magrath to discuss a plan for closer cooperation between DOE/EERE and BAA/NASULGC for the purpose of expanding the access of the DOE to the research and extension capacities of the state universities and land-grant colleges. The objective of this expanded cooperation was to provide access to Extension and Outreach System for delivering products and services of the DOE research and development programs and to develop partnerships in research that would increase the productivity of DOE and NASULGC affiliated institution research programs.

\title{
The Project:
}

The DOE and NASULGC agreed to initiate an initial year pilot effort to meet the purposes of closer cooperation through the development of five projects to explore the potentiality of collaborations. Five projects were developed:

- Expanding the Opportunities for Cooperation and Communication

- Use of Extension and Outreach Systems for the Dissemination and Delivery of DOE/EERE Products and Services

- Youth Education in Science and Technology

- Engaging the Research Capacity of NASULGC Institutions

- Workshops at the DOE Labs for Scientists from the NASULGC-Affiliated Institutions

The projects were conducted for a year in order to gauge what opportunities could be created as a result of this new university/governmental interaction. 
The project was implemented using a coordinating committee and five project teams. The coordinating committee provided the oversight and support of the project teams which were charged with the completion of their designated projects. The five project teams, each lead by regional executive directors for experiment stations or extension services, included representatives from both NASULGC and EERE. The grant provided $\$ 200,000$ with a match (in cash and in-kind) exceeding that amount from the NASULGC institutions that participated in these efforts.

The brochure that follows summarizes the overall project and each of the five individual pilot efforts. All the stated objectives of the project were exceeded.

No new products were developed under the award beyond the refinement of existing curricula for youth education on energy topics. No computer modeling was developed or employed as a result of this project

As a result of the accomplishment under this grant a 3-year grant was awarded to NASULGC to continue the work begun in the inaugural effort. 
This brochure provides an overview of the accomplishments of an emerging partnership that are a source of pride and inspiration. In the past year, five pilot projects were developed to expand access for energy researchers to the extension capabilities of state universities and land-grant colleges, and to benefit university faculty and students through collaboration with federal energy researchers. We are pleased to report that these pilots proved successful, and this success has encouraged us to expand our collaboration. The partnership is now moving toward the creation and implementation of a three-year collaborative agreement that will build on the successes of the pilot projects, both nationally and at the regional level. We are excited about the prospect of accomplishing even more together.

James Fischer and Stan Johnson Partnership Directors 
Addressing Critical National Needs Both the Office of Energy Efficiency and Renewable Energy (EERE) at the Department of Energy (DOE) and the National Association of State Universities and Land-Grant Colleges (NASULGC) are working on issues of national prominence. EERE is pursuing its vision of a clean, prosperous energy future. Its mission is to lead the federal government's research, development, and deployment (RD\&D) efforts in biomass, geothermal, solar, wind, building energy efficiency, and other renewable and energy efficiency technologies aimed at providing reliable, affordable, and environmentally sound energy supplies for America's future.

NASULGC's institutions have enabled many of the intellectual, material, and economic benefits enjoyed by the citizens of our nation. American higher education has a history of successful research and transfer of agricultural and other technologies at land-grant and other educational institutions, and a cooperative extension service that is renowned worldwide.

EERE and NASULGC have invested in developing plans and roadmaps. Both organizations have invested in developing plans and roadmaps. Both are now seeking to engage other organizations with whom they can develop productive partnerships, and build integrated programs that will result in interactive and responsive organizations. And both are seeking to put critical resources to work on problems that communities and the nation face. Our alliance is a natural fit.

Idea for a New Partnership The seeds for a partnership between EERE and NASULGC were planted in the late 1990s by several EERE and NASULGC individuals, including Doug Faulkner; EERE's Principal Deputy Assistant Secretary, and Dr. Stanley Johnson; Vice Provost for Extension at Iowa State University. They recognized that public colleges and universities are the only entity in the U.S. where teaching, research, and outreach programs involving renewable energy and energy efficiency could come together under "one roof" and, at the same time, connect to a national system of universities in each state to create a presence in every county in the U.S.

They proposed a partnership between EERE and NASULGC that would expand the working relationship between member institutions of NASGULC and DOE. This

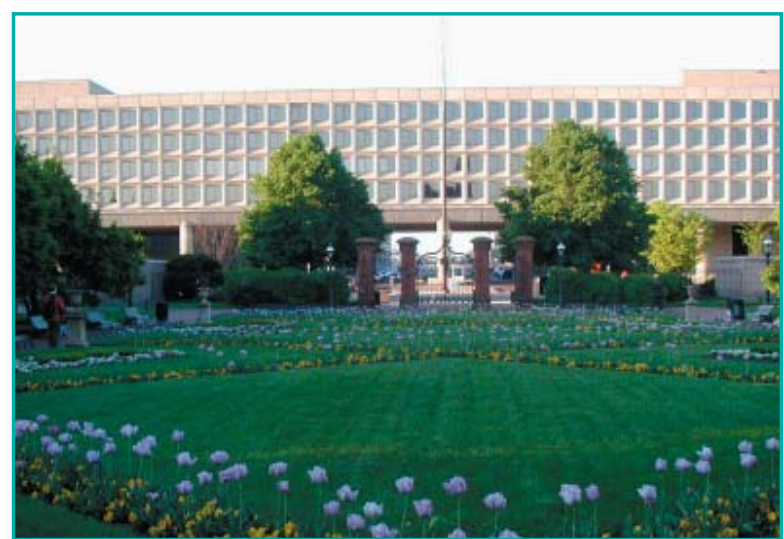

The overall EERE portfolio provides a combination of multiple renewable energy technologies - solar, wind, biomass, geothermal, and others - together with research and development of energy efficiency technologies. Shown: Department of Energy Headquarters (the Forrestal Building) in Washington, D.C.

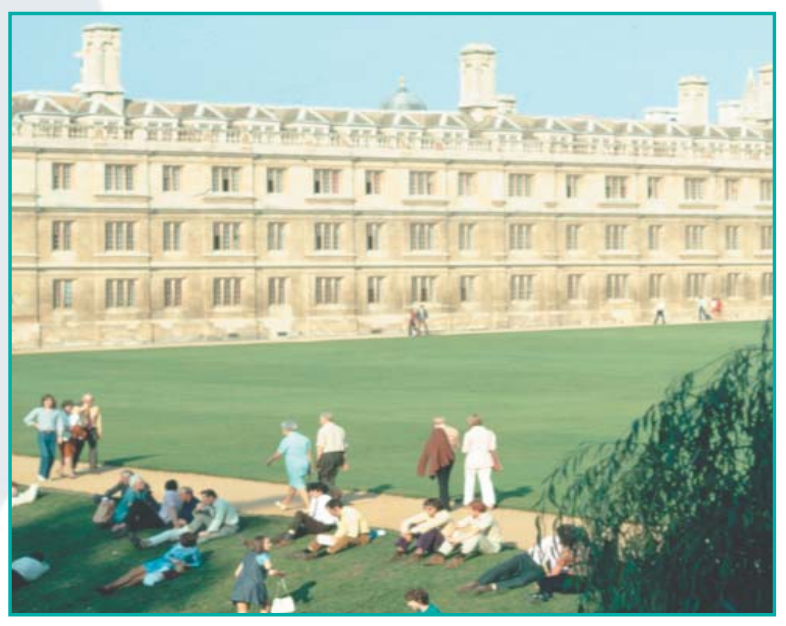

A voluntary association of public universities, landgrant institutions, and many of the nation's public university systems, NASULGC campuses are located in all 50 states, U.S. territories, and the District of Columbia.

would create an opportunity for EERE to more cost-effectively carry out its mission to develop and disseminate energy efficiency and renewable energy production technologies. It would also serve to enhance the research and education capacity of NASULGC institutions by allowing them to interact more closely with EERE's energy research 
and development programs and National Laboratories.

Bringing The Partnership to Life In January 2003, Peter Magrath, the President of NAGULGC, and David Garman, DOE's Assistant Secretary for Energy Efficiency and Renewable Energy, met and agreed to collaborate and to develop and implement a new partnership model.

Dr. James Fischer (who has held previous faculty and administrative positions at Clemson, Michigan State, University of Missouri, and the U. S. Department of Agriculture (USDA)) was hired as a member of the EERE Board of Directors to help build the basis for cooperation with the NASULGC institutions and U.S. higher education more generally. President Peter Magrath designated the NASULGC Board on Agriculture Assembly (BAA) as the NASULGC entity to carry out the partnership. The BAA appointed a committee to coordinate with Dr. Fischer in developing a program of action that would achieve the objectives of the EERE/NASULGC agreement for expanded cooperation. The concept was developed that described a future where the capacities of universities and DOE could be matched in critical areas, to help provide all citizens, including farmers and other rural Americans, with clean, affordable, and bountiful energy. EERE and NASULGC could help bring about this future, it was proposed, by working together to build a partnership. Following the development of this concept, a formal proposal was developed and submitted for consideration. In January of 2004, the formal proposal for five one-year joint pilot projects (described in the table on FY04 Accomplishments) was accepted, and in February 2004, the first meeting of the new partnership was conducted.

FY 2004 Partnership EERE and NASULGC engaged in a collaborative partnership-building activity in fiscal year 2004 (FY04) through joint participation on Leadership Teams for each of the five pilot projects. The intent of this collaboration was to provide access to extension and outreach systems for delivering products and services of the EERE research and development programs, to develop partnerships in research that would increase the productivity of EERE and NASULGC-affiliated institutions' research programs, and to explore the potential for energy curriculum development.

For NASULGC, the benefits of collaborating with EERE include helping its member universities increase their responsiveness and relevance to the practical, current problems of society, and to provide opportunities for faculty and students to gain access to research and new knowledge. In addition, new opportunities for the university Extension programs were explored and discussed by representatives from NASULGC with a Task Force that had been as-

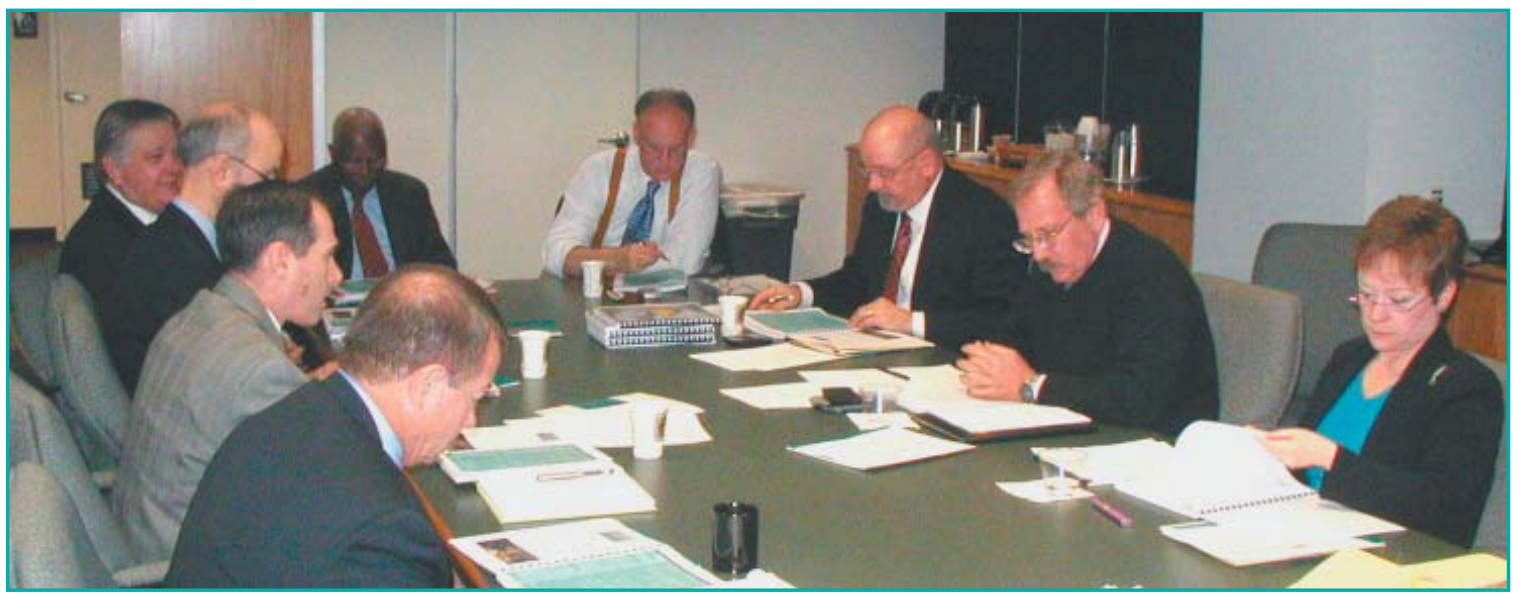

Executive Steering Committee members discussing the progress and future direction of the EERE/

NASULGC partnership at the January 25, 2005 meeting. 

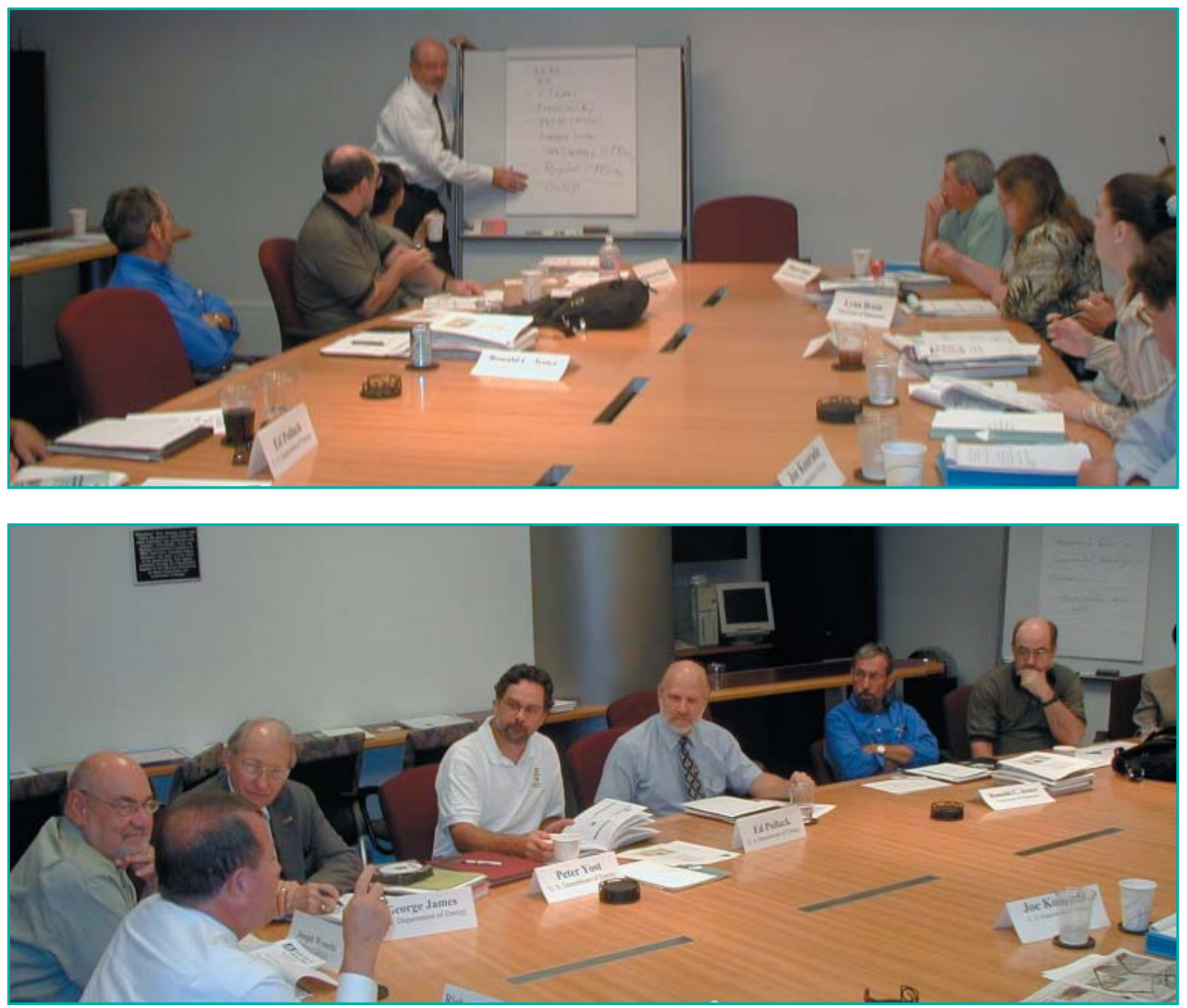

DOE scientists and university Extension officials met together in workshops on energy-efficient housing to disseminate the DOE Building America "Best Practices Guide" to building contractors. (Project 2-A)

sembled by EERE to examine the deployment of energy efficiency and renewable energy technologies.

Overall management for the pilot year partnership has been provided by a 10-person Executive Steering Committee, consisting of key executives from EERE and NASULGC. Leadership for each of the projects has been provided by a Project Leadership Team consisting of senior-level managers from both organizations. Nine EERE personnel and one staff member from the National Renewable Energy Laboratory (NREL), as well as 10 NASULGC personnel, consisting of representatives from NASULGC, the Agricultural Experiment Station, and/or Extension Directors Regional Associations, have served on project leadership teams.

Teleconferencing has enabled team members to conduct partnership business from locations across the U.S. A proj- ect tracking system has been established to monitor the status of the projects. Communication was further enhanced by development of a Web site - http://www.ncfap.org/ specialprojects. Requested white papers defined potential roles for Extension in energy deployment. Highlights from all of the five projects that have helped to lead the successful development of this emerging, synergistic partnership are presented in the table on FY04 Accomplishments.

\section{Next Steps: Moving Toward A Three-Year Collab-} orative Agreement This emerging partnership is now in the process of developing a three-year collaborative agreement, in order to build on successful accomplishments in FY04 and to enhance the pursuit of EERE's and NASULGC's respective missions. While this will initially be a three-year effort, it is envisioned as a longer-term initiative that would achieve significant integration into programs and regional organizations. A detailed listing of activities for FY05 is presented in the table FY05 Activities to Fulfill Objectives. 
(1) Expanding the Opportunities for Cooperation and Communications between NASULGC and DOE/EERE

(2) Use of Extension and Outreach Systems for the Dissemination and Delivery of DOE/EERE Products and Services

(3) Youth Education in Science \& Technology

(4) Engaging the Research Capacities of the Universities and State Colleges

(5) Workshops at the DOE Labs for Scientists from the NASULGC-Affiliated Institutions
- Over 30 presentations concerning EERE and NASULGC activities and capacities.

- Two articles published and a Web site established outlining partnership goals and developments.

- Searchable resume database (Autonomy) containing resumes from faculty at NASULGC institutions who are willing to serve on peer panels, advisory boards, etc. being developed

- Databases for contacting researchers and extension personnel at NASULGC-affiliated institutions expanded and made more useable for making DOE/EERE contacts.

- Two administrators from NASULGC universities appointed to Advisory Boards and several faculty identified to serve on peer review panels.

- Faculty from seven universities participated with EERE's Building America program on residential housing.

- EERE Building America program (Building Sciences Corporation) conducted three-day workshop for faculty.

- Faculty used Building America Best Practices Guide as base material for educational programs in their respective states with feedback to the EERE Building America program.

- Three white papers written on the following topics:

- how a demonstration house can incorporate best energy efficiency practices and be a tool in educational work

- the value added of an Extension Partnership with other agencies, and

- an overview of the components of high-performance housing.

- Four states in the Pacific Northwest - Alaska, Washington, Oregon, and Idaho — along with Kentucky are joining forces to train local extension educators about alternative energy sources and the economic advantages that these sources may provide small/rural communities and the ability of these communities to attract new business and industry.

- The technology selected for trial was supplied by EERE and the National Energy Education Development (NEED), and focused on the "science and energy of light and lighting."

- Youth educators from seven states were trained in Washington, DC on the curriculum during a two-day period (June 2004).

- The curriculum was taught in the 4-H After-School Program over a period of three weeks after the beginning of the academic year (September and October).

- The process showed that the new content could be easily introduced into the curriculum and was manageable by the $4-\mathrm{H}$ professionals.

- The learning outcomes were impressive, with almost all participants taking away from the sessions the main ideas and concepts.

Summary of findings of a survey included:

- Universities can account for funds received from DOE, but not from a sub-agency within DOE; re: EERE.

- $87 \%$ of the research VPs indicated that they had not experienced any difficulty in reaching agreement with DOE on terms and conditions for the handling of IP

- $28 \%$ of the university VPs had concerns relative to the time of notification from DOE relative to deadlines

- Institutional capacity to respond to DOE grants could result from the following:

- limited faculty with an interest in energy-related topics,

- a lack of alignment of DOE programs with SAES/university research capacity,

- the general overall shrinkage of university research faculty,

- a lack of a critical mass of faculty to address DOE/EERE priorities, and

- the cost-sharing requirements imposed by DOE.

- Universities subscribe to various services to keep their faculty informed of grant opportunities. Most popular were the "Community of Science" service, while some noted that they used FedBiz.opps, or SPIN (Sponsored Research Information Network).

- Most effective way to solicit and/or notify universities of opportunities for collaborative research awards from DOE was e-mail notifications directly to faculty, deans, and directors

- Analysis of the USDA Cooperative Research Information System (CRIS) Portfolio for energy-related research identified:

- 16 ARS projects,

- two multi-state projects, and

- 76 individual investigator Hatch projects.

- Workshop held at NREL. Participation included 50 universities, 56 participants for biomass, 26 for solar energy, and two Native American serving institutions and 12 Historically Black Colleges and Universities (HBCUs). 


\section{Objectives}

(1) Enhancing EERE program impact by increasing the working relationship between NASULGC regional associations and EERE regional offices.

(2) Institutionalizing the Extension outreach capacity in EERE programs.

(3) Increase public education about energy by augmenting youth education in science and math with EERE-related interactive modules.

(4) Expanding the joint university/EERE lab workshops to all EERE program areas.

(5) Developing methods to improve the formal exchange between EERE scientists/ engineers and university faculty

\section{FY05 Proposed Project Activities to Fulfill Objectives}

Proposes to link EERE regional offices with the well-developed Cooperative Extension Service networks of offices and technical staff in all U.S. counties to deliver renewable energy education programs.

\section{Why?}

- Builds on 2004 Project 2, which piloted a program utilizing the capacity of the extension system to deliver selected EERE services.

- As result of 2004 Project 2, we learned there are many and varied energy activities throughout the Cooperative Extension System.

- Proposed activities capitalize on existing Extension energy activities and the interest expressed in 2004 Project 2's initial planning efforts.

\section{Process:}

- Organize a national training session to prepare trainers for the regional sessions that will follow. NASULGC institutions with the EERE regions and their state energy offices will send staff and faculty to participate in the regional trainings - up to five will be trained per state.

Proposes expanded partnership-building between EERE programs and the Land-Grants extension system, specifically the Building America program.

\section{Why?}

- Builds on success of 2004 Project 2 where Building America Extension faculty demonstrated successful outreach activities in each EERE region and established working relationships with the Building America personnel and teams.

\section{Process:}

- Expands the number of participating universities.

- Program efforts can be developed at the regional office level where teams will also plan and conduct in each region "Train-the-trainers" workshops for Cooperative Extension personnel relevant to the Building America program's goals and objectives.

Proposes to build on youth education activities in science and education working with 4-H and NEED.

Why?

- Builds on the youth education in science and technology work of FY04.

Process:

- Continue to work with 4-H Council and NEED in the After-School Program with possible expansion to other programs areas including the club, camping, and other major programs.

- Increase the number of educational modules to at least six.

Proposes to expand mechanisms that enhance the interactions between NASULGC institutions and the National Laboratories.

Why?

- Builds and extends activities from Project 5 in FY04.

\section{Process:}

- Facilitate two additional meetings with the DOE Labs that are designed to bring together faculty from the NASULGC-affiliated institutions and scientists and engineers from the Labs.

- One of the training sessions will be at a DOE Lab not under EERE.

- There is also interest in USDA hosting one of these sessions.

Proposes to increase scientists-to-scientist interactions within EERE and NASULGC institutions.

Why?

- Need became apparent in last year's pilot activities.

\section{Process:}

- There are numerous ways to increase these interactions such as sabbaticals, Interagency Personnel Agreements (IPAs), etc. In FY05, the project will focus on IPAs.

- Will identify a "fast track" mechanism to make it easier for scientists to move on IPAs from the NASULGCaffiliated institutions to DOE and vice versa. 


\section{Executive Liaison}

Michael Mills

Office of Energy Efficiency and Renewable Energy

U.S. Department of Energy

1000 Independence Avenue, SW

Washington, DC 20585-0121

Phone: (202) 586-1394

Fax: (202) $586-2096$

E-mail: michael.mills@ee.doe.gov

\section{Coordinator}

Jill Long Thompson

National Center for Food and Agricultural Policy 1616 P. Street, NW - Suite 100

Washington, DC 20036

Phone: (202) 328-5183

Fax: (202) 328-5133

E-mail: longthompson@ ncfap.org

March

\section{www.ncfap.org/specialprojects}

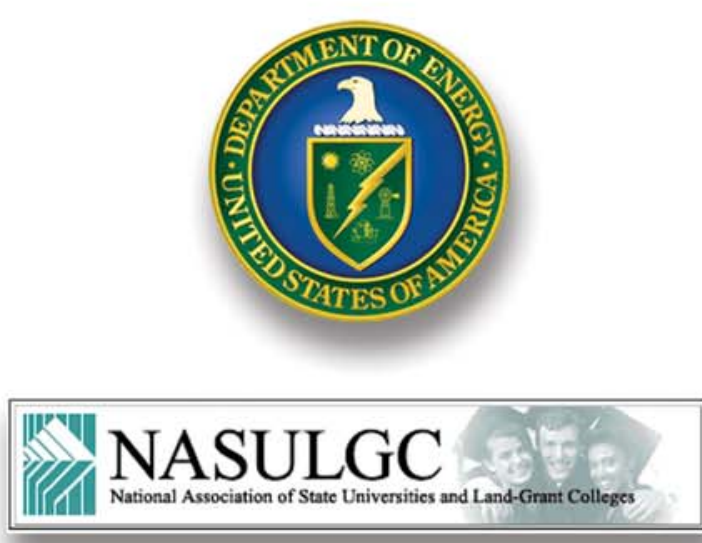

March 2005 